Clim. Past, 9, 1417-1430, 2013

www.clim-past.net/9/1417/2013/

doi:10.5194/cp-9-1417-2013

(C) Author(s) 2013. CC Attribution 3.0 License.

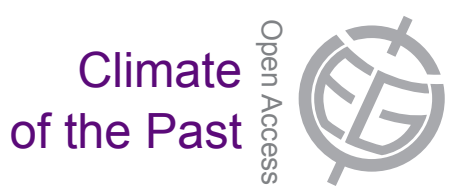

\title{
Megalake Chad impact on climate and vegetation during the late Pliocene and the mid-Holocene
}

\author{
C. Contoux ${ }^{1,2}$, A. Jost ${ }^{2}$, G. Ramstein ${ }^{1}$, P. Sepulchre ${ }^{1}$, G. Krinner ${ }^{3}$, and M. Schuster ${ }^{4}$ \\ ${ }^{1}$ Laboratoire des Sciences du Climat et de l'Environnement/IPSL, UMR8212, CEA/CNRS/UVSQ - \\ Gif-sur-Yvette Cedex, France \\ ${ }^{2}$ Sisyphe, UPMC Paris 6/CNRS, Paris, France \\ ${ }^{3}$ Laboratoire de Glaciologie et de Géophysique de l'Environnement, UJF-Grenoble1/CNRS, Grenoble, France \\ ${ }^{4}$ Institut de Physique du Globe de Strasbourg, UMR7516, CNRS - Université de Strasbourg/EOST, 1 rue Blessig, \\ 67084 Strasbourg Cedex, France
}

Correspondence to: C. Contoux (camille.contoux@1sce.ipsl.fr)

Received: 26 February 2013 - Published in Clim. Past Discuss.: 11 March 2013

Revised: 23 May 2013 - Accepted: 4 June 2013 - Published: 5 July 2013

\begin{abstract}
Given the growing evidence for megalakes in the geological record, assessing their impact on climate and vegetation is important for the validation of palaeoclimate simulations and therefore the accuracy of model-data comparison in lacustrine environments. Megalake Chad (MLC) occurrences are documented not only for the mid-Holocene but also for the Mio-Pliocene (Schuster et al., 2009). At this time, the surface covered by water would have reached up to $\sim 350000 \mathrm{~km}^{2}$ (Ghienne et al., 2002; Schuster et al., 2005; Leblanc et al., 2006), making it an important evaporation source, possibly modifying climate and vegetation in the Chad Basin. We investigated the impact of such a giant continental water area in two different climatic backgrounds within the Paleoclimate Model Intercomparison Project phase 3 (PMIP3): the late Pliocene (3.3 to $3 \mathrm{Ma}$, i.e. the mid-Piacenzian warm period) and the mid-Holocene (6 kyr BP). In all simulations including MLC, precipitation is drastically reduced above the lake surface because deep convection is inhibited by overlying colder air. Meanwhile, convective activity is enhanced around MLC because of the wind increase generated by the flat surface of the megalake, transporting colder and moister air towards the eastern shore of the lake. The effect of MLC on precipitation and temperature is not sufficient to widely impact vegetation patterns. Nevertheless, tropical savanna is present in the Chad Basin in all climatic configurations, even without MLC presence, showing that the climate itself is the driver of favourable environments for sustainable hominid habitats.
\end{abstract}

\section{Introduction}

The Chad Basin is a vast endorheic basin located in northcentral Africa, between 5 and $25^{\circ} \mathrm{N}$ (Fig. 1), covering approximately $2.5 \times 10^{6} \mathrm{~km}^{2}$. At present, climate is sub-desertic to tropical humid (Sudanian), with precipitation ranging from 0 to $900 \mathrm{~mm} \mathrm{yr}^{-1}$. The wind regime is dominated by the Harmattan northeasterly wind during the dry season (November to March) and the monsoon southwesterlies during the wet season (from June to September). A Harmattan wind pattern is inferred from coastal morphosedimentary structures for the mid-Holocene (Bouchette et al., 2010). Present-day Lake Chad is mainly fed by the Chari-Logone river system coming from the southern part of the basin $(82 \%$ of total inputs, Leblanc et al., 2011). Because the Chad Basin is endorheic and relatively flat, climatic variations have an important impact on the lake extent, as evidenced by seasonal fluctuations as well as by historical and geological archives. Since 1960, Lake Chad has shrunk from 25000 to $6000 \mathrm{~km}^{2}$ on average, mainly because of a decrease in rainfall and associated Chari-Logone river flow to the lake (Olivry et al., 1996). At longer time scales such as precession cycles, Lake Chad extent has proven to vary considerably. The presence of Megalake Chad (MLC) in the mid-Holocene is widely attested from lake deposits and from coastal morphosedimentary structures (e.g. Tilho, 1925; Pias and Guichard, 1957; Grove and Pullan, 1963; Maley, 1977; Kusnir and Moutaye, 1997; Ghienne et al., 2002; Schuster et al., 2003, 


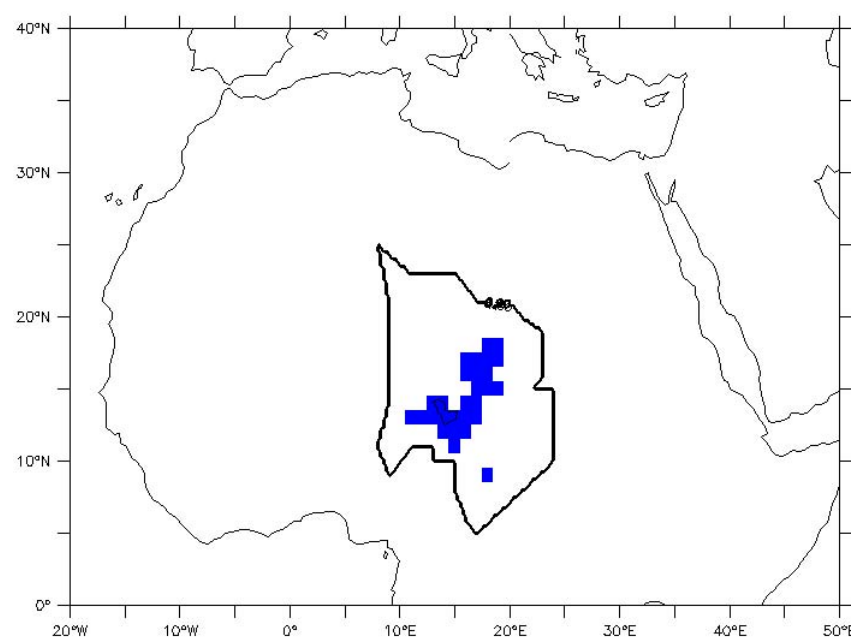

Fig. 1. Imposed lake surface in LMDZ4 for "lake" experiments. The black contour line represents the Chad hydrological basin (catchment) limits.

2005, 2009; Drake and Bristow, 2006; Leblanc et al., 2006; Bouchette et al., 2010). At the time, this large water body reached more than $350000 \mathrm{~km}^{2}$ (Ghienne et al., 2002; Schuster et al., 2005; Leblanc et al., 2006) with wind-driven hydrodynamics (Bouchette et al., 2010). Similar MLC episodes are thought to have occurred during the Miocene and the Pliocene (Schuster et al., 2001, 2006; Griffin, 2006), supposedly linked to a northward shift of the West African monsoon system. In particular, sediments from the northern part of the Chad Basin describe lacustrine occurrences from 7 to $3 \mathrm{Ma}$ (Schuster et al., 2001, 2006, 2009; Lebatard et al., 2010), associated with the presence of fossil vertebrate fauna and two hominids (Sahelanthropus tchadensis, $7 \mathrm{Ma}$, Brunet et al., 2002; and Australopithecus bahrelghazali, 3.6 Ma, Brunet et al., 1995), in a mosaic vegetation landscape (Brunet et al., 1997). Climate models for the mid-Holocene (Braconnot et al., 2007) and the Pliocene (Haywood et al., 2013) generally simulate more precipitation in North Africa, allowing drainage system reactivation and large lake development for these periods.

Investigating potential climate and vegetation perturbations induced by open continental water surfaces is the subject of many studies (e.g. Coe and Bonan, 1997; Broström et al., 1998). The impact of the desiccation of pre-industrial Lake Chad $\left(25000 \mathrm{~km}^{2}\right)$ on climate was investigated by Lauwaet et al. (2012). Using a mesoscale regional atmospheric model coupled to a soil-vegetation-atmosphere transfer (SVAT) model, they found that total precipitation amounts were hardly affected by the presence of Lake Chad compared to no lake or to a small one $\left(6000 \mathrm{~km}^{2}\right)$. Filled pre-industrial Lake Chad increases precipitation over the lake and its eastern border, but large-scale atmospheric processes are not affected, and far-field impact is unclear and variable (Lauwaet et al., 2012). MLC impact on climate has been tested several times with numerical simulations as well, but only in the mid-Holocene or pre-industrial climates. Broström et al. (1998) used an atmospheric general circulation model (AGCM) to study the impact of vegetation, MLC and wetlands on North African climate during the midHolocene, but using present-day sea-surface temperatures (SSTs). They found that vegetation forced the African monsoon roughly $300 \mathrm{~km}$ northward, while MLC and wetlands only produced local changes, with no northward shift of the monsoon. Sepulchre et al. (2009) and Krinner et al. (2012) investigated African climate responses to different surface conditions using the LMDZ4 AGCM including a lake surface module (Krinner, 2003). Sepulchre et al. (2009) carried out sensitivity tests for the MLC presence in a preindustrial climate, and found that it had a negative feedback on the Chad Basin water balance, and that deep convection processes were inhibited by the cold water surface of the megalake, preventing precipitation and associated local water recycling. Krinner et al. (2012), using 9 kyr SSTs previously simulated with an AOGCM, accounting for midHolocene lakes (including MLC), wetlands and vegetation feedback all over northern Africa, found a similar negative feedback of MLC over its surface, but suggested that at larger scale, these surface conditions locally more than doubled the simulated precipitation rates outside the Chad Basin, in the dry areas of central and western Sahara.

The present study aims at investigating the contribution of MLC on climate and vegetation in two different contexts: the mid-Holocene and the late-Pliocene warm period. Considering MLC occurrences during the Mio-Pliocene and the availability of boundary conditions for the simulation of the mid-Piacenzian warm period (mPWP) climate, we have the opportunity to test the impact of MLC in a new climatic context. We investigate MLC impact on climate and vegetation in the mid-Holocene (6 kyr BP) and in two configurations of the mPWP using the LMDZ4 AGCM including a lake surface module (Krinner, 2003). It is possible to study the regional impact of MLC thanks to the zoomed grid of the LMDZ model. While the African Humid Period of the midHolocene is well driven by orbital forcing, the mPWP time slice is much longer (from 3.3 to $3 \mathrm{Ma}$ ) and contains several orbital cycles. Indeed, it is known that precession can favour a northern position of the ITCZ, thus deeply modifying the monsoon pattern during the mid-Holocene (Marzin and Braconnot, 2009), coinciding with the last occurrence of MLC. Before $2.8 \mathrm{Ma}$, the African monsoon is thought to have been controlled by precession as well, with higher humidity when perihelion coincides with boreal summer (deMenocal et al., 1995, 2004). Considering that the impact of MLC might be different in different climatic backgrounds, and varying with monsoon intensity, two climatic configurations of the late Pliocene are investigated: one uses SSTs calculated in the frame of the PlioMIP, i.e. using late-Pliocene boundary conditions and pre-industrial orbital configurations, the other uses SSTs calculated using late-Pliocene boundary 
Table 1. Boundary conditions for the simulations.

\begin{tabular}{|c|c|c|c|c|c|c|c|}
\hline Expt & $\begin{array}{l}\text { SSTs and } \\
\text { sea ice }\end{array}$ & $\mathrm{CO}_{2}$ & $\begin{array}{l}\text { Orbital } \\
\text { parameters }\end{array}$ & Ice sheets & $\begin{array}{l}\text { Albedo, } \\
\text { roughness }\end{array}$ & Topography & $\begin{array}{l}\text { Lake Chad } \\
\text { surface }\end{array}$ \\
\hline Control & 1988-2007 mean & 280 & Modern & Modern & Modern & Modern & Present-day \\
\hline Plio & From AOGCM* & 405 & Modern & PlioMIP & PlioMIP & PlioMIP & Present-day \\
\hline Plio_lake & From AOGCM* & 405 & Modern & PlioMIP & PlioMIP & PlioMIP & MLC \\
\hline Plio_max & From AOGCM* & 405 & $\begin{array}{l}\text { Insolation max. } \\
\text { at } 30^{\circ} \mathrm{N} \text { at } \\
\text { summer solstice }\end{array}$ & $\begin{array}{l}\text { Antarctica as } \\
\text { PlioMIP, no Green- } \\
\text { land Ice Sheet }\end{array}$ & PlioMIP & $\begin{array}{l}\text { PlioMIP except } \\
\text { for Greenland }\end{array}$ & Present-day \\
\hline Plio_max_lake & From AOGCM* & 405 & $\begin{array}{l}\text { Insolation max. } \\
\text { at } 30^{\circ} \mathrm{N} \text { at } \\
\text { summer solstice }\end{array}$ & $\begin{array}{l}\text { Antarctica as } \\
\text { PlioMIP, no Green- } \\
\text { land Ice Sheet }\end{array}$ & PlioMIP & $\begin{array}{l}\text { PlioMIP except } \\
\text { for Greenland }\end{array}$ & MLC \\
\hline MidHol & From AOGCM* & 280 & PMIP for $6 \mathrm{kyr}$ & Modern & Mid-Holocene & Modern & Present-day \\
\hline MidHol_lake & From AOGCM* & 280 & PMIP for $6 \mathrm{kyr}$ & Modern & Mid-Holocene & Modern & MLC \\
\hline
\end{tabular}

SSTs specified with a * are implemented as anomalies.

conditions and an orbital configuration with perihelion in summer, corresponding to the maximum of insolation at $30^{\circ} \mathrm{N}$ between 3.3 to $3 \mathrm{Ma}$. These climate simulations will help clarify the feedback role of MLC on climate by testing this impact in a new climatic context, the late Pliocene. The simulated climates are then used to force the vegetation model BIOME4 (Kaplan et al., 2003), which is widely used to simulate palaeovegetation with GCM outputs (e.g. Harrison and Prentice, 2003) and accounts for $\mathrm{CO}_{2}$ concentration variations. This study investigates the local and regional feedbacks of MLC on climate and vegetation in different climatic backgrounds and orbital configurations for which results are compared in order to exhibit common robust features and, if possible, background climate-dependent features. In this respect, it is the first time that MLC impact has been investigated in the late-Pliocene climate.

\section{Models description}

\subsection{LMDZ4_LAKE atmospheric model}

We use the LMDZ4 atmospheric general circulation model (AGCM) (Hourdin et al., 2006) including a water surface module (Krinner, 2003) composed of eight layers, which represent the thermal and hydrological processes occurring above and beneath the continental water surface. The model explicitly represents the penetration and absorption of sunlight into the lake levels, as well as heat conduction, convective overturning, water phase changes, sensible and latent turbulent surface heat fluxes and water balance (Krinner, 2003). Lake surface is fixed and is an additional surface type to the LMDZ4 scheme already including ocean, sea ice, land ice and land. In this study, vegetation is prescribed through albedo and roughness boundary conditions, and the surface scheme is a bucket model. Although water balance of the lake is calculated, the absence of a surface water routing scheme makes it inappropriate to use the model for prediction of lake level and extent. This model can then only be used as a predictor of lake impact on climate. Resolution is zoomed to $\sim 100 \mathrm{~km}$ for the Lake Chad region, and mean grid spacing is $3.75^{\circ} \times 2.5^{\circ}$. The atmosphere has 19 vertical layers. Parameterization of convection is the Emanuel scheme (see Hourdin et al., 2006). Previous studies used this model to investigate the climatic impact of MLC in a pre-industrial context (Sepulchre et al., 2009) and during the mid-Holocene (Krinner et al., 2012).

\subsection{BIOME4 vegetation model}

BIOME4 is an equilibrium biogeography model developed by Kaplan et al. (2003) which is based on BIOME3 (Haxeltine and Prentice, 1996). It is widely used for the simulation of equilibrium vegetation in past climates, including the pre-Quaternary climates of the Tortonian (Pound et al., 2011) and Piacenzian (Salzmann et al., 2008; Kamae and Ueda, 2012) and the more recent mid-Holocene (Kaplan et al., 2003; Krinner et al., 2012). This model simulates the equilibrium distribution of 28 biomes. This potential natural vegetation is determined by the ranking of 12 plant functional types (PFTs) which have different bioclimatic limits (temperature resistance, moisture requirement, sunshine amount). Competition between the PFTs is a function of net primary productivity (NPP) and uses an optimization algorithm to calculate the maximum sustainable leaf area index (LAI). NPP, LAI and mean annual soil moisture are then classified empirically to determine the predominant biome (Haxeltine and Prentice, 2003). Input data of the model include the mean monthly climate (temperature, precipitation, sunshine and minimum temperature), soil physical properties and atmospheric $\mathrm{CO}_{2}$ concentration. 
Table 2. Orbital parameters used for the different experiments.

\begin{tabular}{lccr}
\hline Expt & Eccentricity & Obliquity & $\begin{array}{r}\text { Precession } \\
\text { angle }\end{array}$ \\
\hline Control, Plio & 0.016715 & 23.441 & 102.7 \\
Plio_max & 0.052115 & 23.641 & 271.4 \\
MidHol & 0.018682 & 24.105 & 0.87 \\
\hline
\end{tabular}

\section{Experimental design and boundary conditions}

\subsection{AGCM experiments}

Three climatic configurations are investigated: two are latePliocene (mPWP) experiments (Plio and Plio_max simulations) and one is mid-Holocene (6 kyr, MidHol simulations). The two late-Pliocene experiments differ by the imposed SSTs and orbital configuration, which are described in Sect. 3.1.2. For each simulation, integration time is $70 \mathrm{yr}$, and climatologies are performed on the last $50 \mathrm{yr}$. To study the impact of the lake on these past climates, we carry out two simulations for each climatic configuration (except the control): one with imposed MLC surface (Fig. 1, "lake" simulations), the other one with a single grid point defined as a lake surface, which roughly corresponds to present-day Lake Chad. In order to be the closest possible to the topographic reconstruction of MLC extent from Schuster et al. (2005), we ran the HYDRA routing surface model (Coe, 2000) with direct outputs of the standard PlioMIP Pliocene coupled model simulation, which completely fills MLC and then outflows into the Benue river, providing the maximum extent of MLC. The simulated extent and shape were then regridded to $1^{\circ} \times 1^{\circ}$ resolution, and define MLC surface boundary condition as shown in Fig. 1. Lake depth is fixed to $20 \mathrm{~m}$ at the beginning of the simulation. In total, six climatic simulations plus the control run were carried out. All these simulated climate anomalies are then used to force the BIOME4 vegetation model. A summary of the boundary conditions for each simulation can be found in Table 1 . Orbital parameters for each simulation can be found in Table 2. For the mid-Holocene at $6 \mathrm{kyr}$, they are defined following the PMIP3 protocol. For Plio simulations, they are set to pre-industrial values. For Plio_max simulations, they correspond to the maximum of insolation of the PlioMIP interval at $30^{\circ} \mathrm{N}$ at summer solstice.

\subsubsection{Control 0 kyr simulation}

For the control simulation, boundary conditions (i.e. albedo, roughness, topography and ice sheets) are set to modern. Imposed SSTs are the climatological mean value for 1988-2007 from the AMIP 2 dataset (Fig. 2a). Greenhouse gases, solar constant and orbital parameters are set to pre-industrial values as required by CMIP5/PMIP3; that is, solar constant is $1365 \mathrm{Wm}^{-2}, \mathrm{CO}_{2}$ content is $280 \mathrm{ppm}, \mathrm{CH}_{4}$ content is $760 \mathrm{ppb}$ and $\mathrm{N}_{2} \mathrm{O}$ content is $270 \mathrm{ppb}$.

\subsubsection{Pliocene experiments}

For Pliocene experiments, we investigated two different climatic configurations. First, the standard late-Pliocene (midPiacenzian) simulations, called Plio, have anomalies of SSTs and sea-ice cover calculated with the IPSL-CM5A AOGCM in the PMIP3/PlioMIP framework (Fig. 2b). This AOGCM simulation is described in detail in Contoux et al. (2012) and corresponds to PlioMIP Experiment 2 (Haywood et al., 2011). Because the precession parameter varies during the late-Pliocene time slab of $300 \mathrm{kyr}$, and can favour a more northerly position of the ITCZ (e.g. deMenocal, 2004), we investigated a second climatic configuration called Plio_max. SST anomalies for this simulation are calculated with the IPSL-CM5A model, starting from a previous Pliocene run, changing the orbital configuration to the maximum of insolation during summer solstice at $30^{\circ} \mathrm{N}$ between 3.3 and $3 \mathrm{Ma}$ (Table 2), based on Laskar et al. (2004). The maximum of insolation at $30^{\circ} \mathrm{N}$ is simultaneous to the maximum of insolation at $65^{\circ} \mathrm{N}$ and occurs at $3.039 \mathrm{Ma}$. This is very similar to the Plio_NHmax configuration used in Dolan et al. (2011). The calculated SSTs are then imposed as anomalies in the LMDZ4 simulation (Fig. 2c), which is also forced with this orbital configuration (Tables 1 and 2). This insolation forcing globally warms the Northern Hemisphere SSTs and cools the Southern Hemisphere SSTs compared to the Plio simulations. Temperatures in the Gulf of Guinea are cooler than in the Plio simulation. All Pliocene SSTs show an important warming in the North Atlantic and a moderate warming in the Gulf of Guinea (from 1 to $2.5^{\circ} \mathrm{C}$ ), an area possibly impacting moisture amount in the Chad region (e.g. Sepulchre et al., 2009). Pliocene SST anomalies (Plio experiment only) in the eastern Atlantic compares well with some ODP sites data (Dowsett et al., 2013). For example, site ODP 659 , situated off the coast of Mauritania at $18^{\circ} \mathrm{N}$, shows a warm anomaly of $2.26^{\circ} \mathrm{C}$, while the simulated anomaly with IPSL-CM5A is $2.3^{\circ} \mathrm{C}$. Site ODP 958, situated more northerly at $23^{\circ} \mathrm{N}$, compares also well with modelled SST, with a warming anomaly of $2.29^{\circ} \mathrm{C}$ compared to modelled $2.03{ }^{\circ} \mathrm{C}$. Other sites of the eastern tropical Atlantic (ODP 667 and 661 and DSDP 366, between 4 and $10^{\circ} \mathrm{N}$ ) show no change or a warming of maximum $1{ }^{\circ} \mathrm{C}$, whereas the model simulates between 1.5 and $1.8^{\circ} \mathrm{C}$ of warming (Dowsett et al., 2013). For the North Atlantic, model SST anomalies are several degrees colder than SST estimates from Dowsett et al. (2010), but this is a general feature of all models in the PlioMIP (Dowsett et al., 2013). For all Pliocene experiments, albedo and roughness are calculated from the mid-Piacenzian biome vegetation dataset of Salzmann et al. (2008). The main features of this vegetation reconstruction are the reduction of deserts and the northward shift of temperate biomes. $\mathrm{CO}_{2}$ is fixed to $405 \mathrm{ppm}$ (Haywood et al., 2010). Ice sheets are 


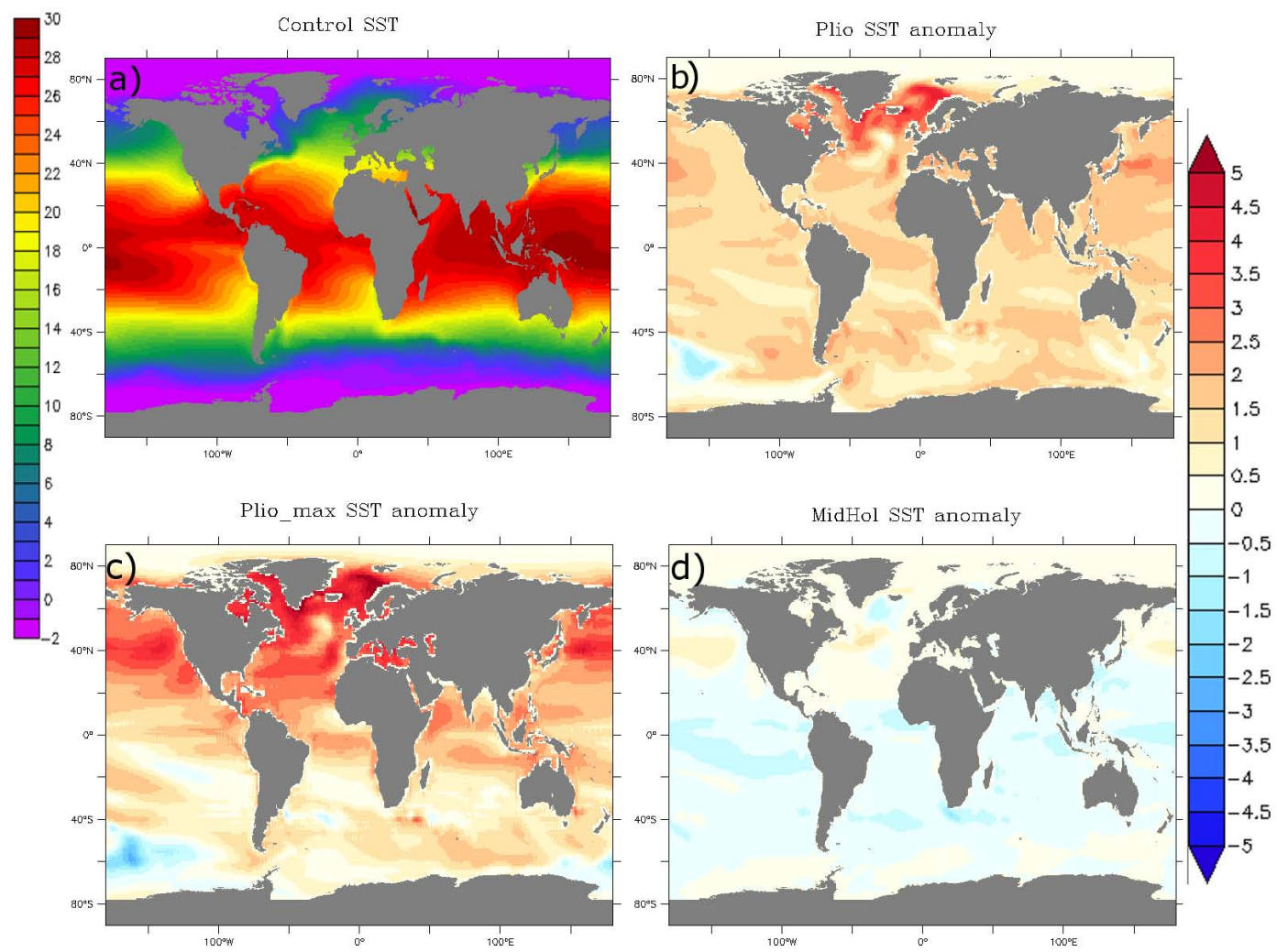

Fig. 2. SSTs imposed in LMDZ4 for (a) control (b) Plio, (c) Plio_max and (d) MidHol experiments, (b-d) expressed as difference from the control SSTs (1988-2007 mean), in ${ }^{\circ} \mathrm{C}$.

mid-Pliocene; that is, the Greenland Ice Sheet is reduced by roughly $50 \%$ and Antarctica by roughly $33 \%$ (Hill et al., 2007; Hill, 2009), except for Plio_max experiments, where the Greenland Ice Sheet was removed, following the conclusions of Dolan et al. (2011). Anomalous mid-Pliocene topography is prescribed (Edwards, 1992; Sohl et al., 2009) following the guidelines of PlioMIP (Haywood et al., 2010), except for Plio_max experiments. For this last experiment, ice-free Greenland topography is calculated with the Grisli ice-sheet model (Ritz et al., 2001) in order to take into account isostatic rebound, and Pliocene anomalous topography is used everywhere else.

\subsubsection{Mid-Holocene experiments}

For the mid-Holocene experiments (MidHol and MidHol_lake), orbital configuration is as stated in PMIP3 for the mid-Holocene (Table 2). $\mathrm{CO}_{2}$ and ice sheets are preindustrial, following the PMIP3 protocol. A first simulation with LMDZ4 was carried out with the control vegetation, from which climatic variables were used to calculate a vegetation distribution for the mid-Holocene with the BIOME4 model. The resulting vegetation, in which the Sahara is smaller than at present, is used to calculate albedo and roughness for the mid-Holocene simula- tions. We use anomalies of SSTs and sea-ice cover calculated with the IPSL-CM5A AOGCM, in the PMIP3 framework (Fig. 2d). This AOGCM simulation is described in Kageyama et al. (2013). Contrary to Pliocene SSTs, MidHol SSTs show a decrease in temperature of about 0.5 to $1{ }^{\circ} \mathrm{C}$ in the Gulf of Guinea. In order to assess the quality of these simulated SSTs, we use the GHOST database from Leduc et al. (2010) to do a model-data comparison of SST anomalies at $6 \mathrm{kyr}$ BP. We take the difference between the value for $6 \mathrm{kyr} \mathrm{BP}$ and the core top to calculate anomalies (as in Hargreaves et al., 2013). Since alkenones and $\mathrm{Mg} / \mathrm{Ca}$ show opposite trends throughout the Holocene for the Gulf of Guinea and some North Atlantic sites, we decided to use only alkenone data, despite the fact that high-latitude alkenone SST records could be biased towards summer month temperatures (Leduc et al., 2010; Prahl et al., 2010). For the Gulf of Guinea, alkenone-derived SSTs describe colder conditions at $6 \mathrm{kyr} \mathrm{BP}\left(-1.9^{\circ} \mathrm{C}\right)$ which are reproduced by the model, although not to the right amplitude (only $-0.44{ }^{\circ} \mathrm{C}$ for the modelled SST anomaly). Off the coast of Mauritania, at $19^{\circ} \mathrm{N}$, the modelled anomaly $\left(+0.34^{\circ} \mathrm{C}\right)$ correctly reproduces the warmer conditions seen in the data $\left(+0.5^{\circ} \mathrm{C}\right)$, although slightly more in the south at $18.6^{\circ} \mathrm{N}$, warmer conditions are depicted in the data $\left(+0.8^{\circ} \mathrm{C}\right)$, whereas the model barely finds any change $\left(+0.1^{\circ} \mathrm{C}\right)$. In the North Atlantic, 

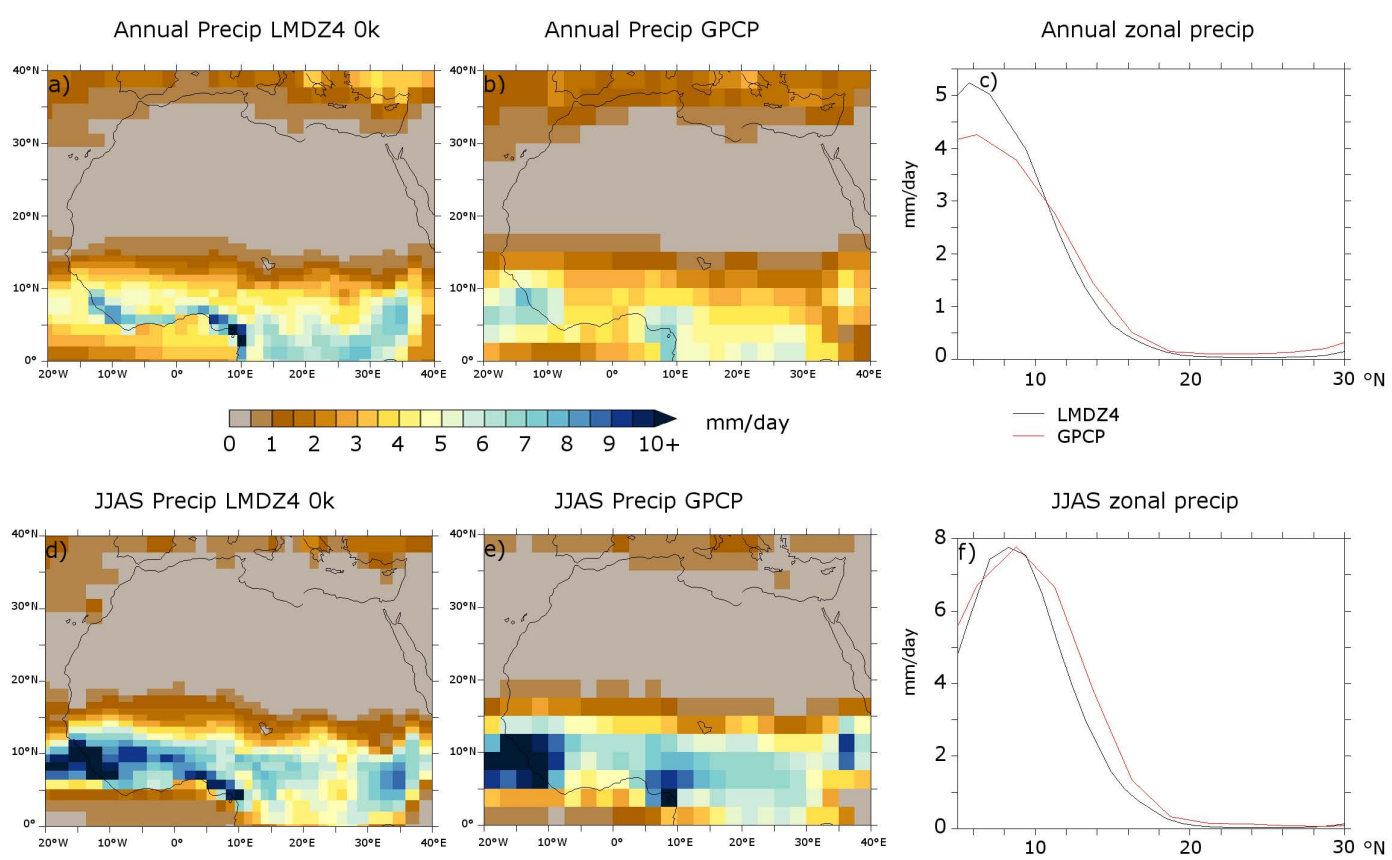

Fig. 3. Top: comparison of annual mean precipitation between the control run (left) and GPCP mean precipitation for years 1979-2010 (centre). Bottom: same for June to September mean precipitation.

only two data points are available in the alkenone database, and the one north of Iceland falls on one model land grid point. The last point is located south of Iceland, at $58.76^{\circ} \mathrm{N}$, and depicts a warm anomaly of $0.2^{\circ} \mathrm{C}$. The modelled SST anomaly is negative on the annual average $\left(-0.61^{\circ} \mathrm{C}\right)$, but with warm anomalies occurring in July $\left(+0.07^{\circ} \mathrm{C}\right)$, August $\left(+0.8^{\circ} \mathrm{C}\right)$ and September $\left(0.18^{\circ} \mathrm{C}\right)$, i.e. in summer.

\subsection{BIOME4 simulations}

Monthly mean temperature, precipitation, sunshine and annual minimum temperature anomalies of the control run were computed from the last $50 \mathrm{yr}$ of each climate simulation and were added to the modern climatology from Leemans and Cramer (1991). This anomaly procedure is widely used (e.g. Kaplan et al., 2003; Haywood et al., 2009) and helps to reduce the climate model simulations' biases. Soil texture and water-holding capacity were unchanged compared to the present. $\mathrm{CO}_{2}$ is specified to $405 \mathrm{ppm}$ for all the Pliocene experiments, and to $280 \mathrm{ppm}$ for the mid-Holocene experiments. BIOME4 is run on a $0.5^{\circ} \times 0.5^{\circ}$ grid.

\section{Results}

\subsection{North African rainfall in the control run}

Annual mean and June to September precipitation over North Africa simulated for the control run are compared to the GPCP Version 2.2 dataset (Adler et al., 2003; Huffman et al., 2009 ) in Fig. 3. The model overestimates annual mean pre- cipitation in the equatorial zone (from 0 to $7^{\circ} \mathrm{N}$ ), but well represents the transition from Sudanian to desertic zones (from $10^{\circ} \mathrm{N}$ to the Sahara), although with a slight underestimation. Regarding monsoon precipitation, the model is in good agreement with GPCP data on the equatorial zone, but from 10 to $25^{\circ} \mathrm{N}$, precipitation is also slightly underestimated, particularly from 12 to $16^{\circ} \mathrm{N}\left(-1 \mathrm{mmday}^{-1}\right)$. It means that for the Sahelian zone, the annual amount of precipitation is correctly represented but is too widely distributed throughout the year. Summer precipitation response to a given perturbation might thus be slightly underestimated in the model.

\subsection{North African rainfall in the late Pliocene and mid-Holocene}

First, all simulations are more humid than the control between 10 and $20^{\circ} \mathrm{N}$ (Fig. 4). Plio configuration is generally more humid than the control, except between 30 and $40^{\circ} \mathrm{N}$ (Fig. 4, red line). Plio_max configuration is characterized by a much broader ITCZ, hence reduced precipitation in the equatorial zone between 3 and $12^{\circ}$, but much wetter tropics and subtropics from 12 to $30^{\circ} \mathrm{N}$ (Fig. 4, blue line) compared to the control run. MidHol simulation is more humid than the control, except slightly drier from 6 to $9^{\circ} \mathrm{N}$. MidHol simulation is also more humid than Plio from 10 to $20^{\circ} \mathrm{N}$. Despite these changes, the Chad Basin is still influenced by southwesterly monsoon winds in summer (Fig. 5, left) and northeastern Harmattan wind in winter for all simulations (Fig. 5, right). 


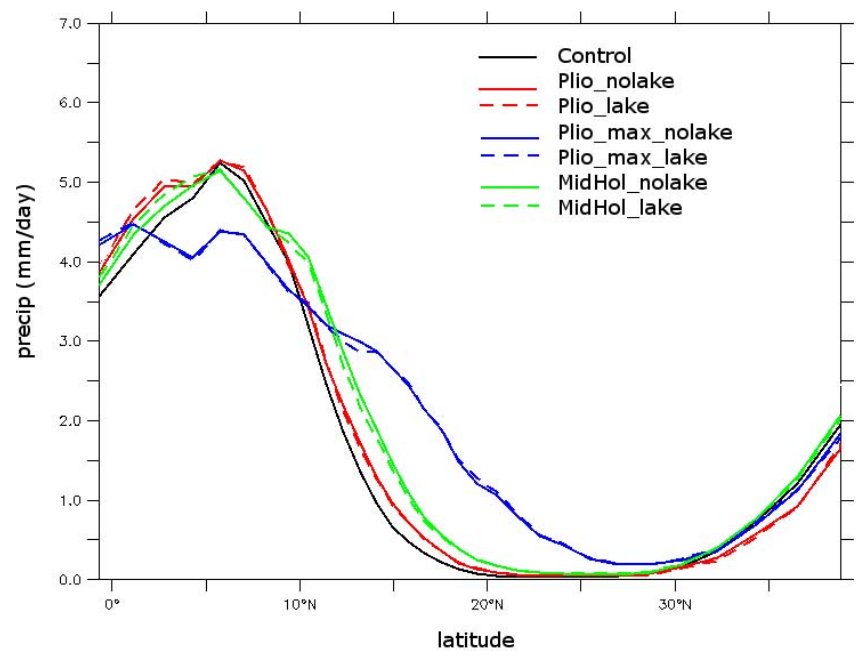

Fig. 4. Mean annual precipitation simulated with LMDZ4 in function of latitude, averaged over $20^{\circ} \mathrm{W}$ to $40^{\circ} \mathrm{E}$.

During summer months, in Plio simulation, there is an increase in precipitation over the eastern part of the Chad Basin, and over central Africa compared to the control run. In Plio_max simulation, the summer monsoon over West Africa is shifted several degrees northward, while over central and eastern Africa, precipitation increases particularly between 15 and $22^{\circ} \mathrm{N}$. Precipitation is increased by more than $5 \mathrm{mmd}^{-1}$ over the central-eastern part of the Chad Basin. In the MidHol simulation, patterns are similar to Plio_max, but with lesser intensity (up to $+2.5 \mathrm{mmd}^{-1}$ in the Chad Basin). The West African summer monsoon is shifted several degrees northward, with local increases up to $3.5 \mathrm{~mm} \mathrm{~d}^{-1}$ over West Africa. Summer precipitation also increases in the eastern part of the Chad Basin up to $2 \mathrm{mmd}^{-1}$. Concerning the winter monsoon (Fig. 5, right), precipitation increases in the Plio simulation. In contrast, in Plio_max and MidHol simulations, the precipitation front is narrower and shifted southward, though with lesser intensity in the MidHol simulation. A common feature of these simulations is the northward shift of the ITCZ during summer months compared to the control run, controlled by the reduced latitudinal temperature gradient in the Northern Hemisphere (Davis and Brewer, 2009), with increased southwesterlies over central to eastern parts of the Sahara (Fig. 5, left). Similarly to the present, precipitation falls on the Chad Basin only during summer months. Increased precipitation over the Chad Basin in all the simulations agree with the possibility of MLC being present in the basin. We will now investigate the impact of such a water surface area on climate and vegetation in order to understand its role in the development of sustainable conditions for hominid presence.

\subsection{MLC impact on climate}

First, the presence of MLC does not impact zonal-average precipitation over the northern part of the African continent (Fig. 4). In all simulations there is no northward shift of the precipitation front induced by the presence of MLC. Over the Chad Basin, the wind regime varies throughout the year, and precipitation only falls during the monsoon season under southwesterly winds conditions. During the rest of the year (October to May), the precipitation front does not reach MLC, and the presence of the megalake does not generate any precipitation. Considering this aspect, we restrict our analysis to summer months means, which display the same patterns as annual means. Regarding the spatial distribution of precipitation (Fig. 6), the most striking impact of MLC is a reduction of precipitation above the surface of the lake in the three climatic configurations (from -1 to $-5 \mathrm{~mm} \mathrm{~d}^{-1}$ ). This is consistent with previous studies (Sepulchre et al., 2009; Krinner et al., 2012) and is well explained by the following: since the lake is generally colder than the surrounding environment, low-level air becomes cooler and denser (Fig. 7) and stabilizes the atmosphere, preventing deep convection and associated rainfall. This mechanism is observed in both Pliocene simulations and in the mid-Holocene one, suggesting it is a robust feature appearing in different background climates. In the meantime, convective activity increases around MLC, especially to the east. Southwesterly winds are enhanced above the surface of the lake due to the reduced roughness length over the flat surface (Figs. 6 and 8), generating convective activity at the northeast of MLC, in the three simulations. Similarly, the effect of pre-industrial Lake Chad on climate is to increase convective activity downwind of the lake (Lauwaet et al., 2012). Moreover, MLC, especially its northern part, is a centre of higher pressure (Fig. 7), generating clockwise winds that can be seen in Fig. 7, which are responsible for the increase of precipitation in the southeast of the lake in the three simulations (Fig. 6). Significant precipitation response outside the Chad Basin is variable in the three simulations and generally not above $0.5 \mathrm{mmd}^{-1}$. This result is different from that of Krinner et al. (2012), in which an increase in precipitation due to MLC and wetlands is depicted on the zonal average, especially from 15 to $25^{\circ} \mathrm{N}$. The differences between the two studies and the possible reasons for divergent results are discussed in the Discussion section.

\subsection{Biome distribution during the Pliocene and the mid-Holocene}

Although there are major changes in the vegetation response between the three different climates, MLC impact in each climatic context is small (Fig. 9). This result depicts the climate as the main driver of vegetation pattern in the Chad Basin during these periods. Plio simulations (Fig. 9a and b) show an extent of tropical savanna up to $15^{\circ} \mathrm{N}$, and xerophytic 


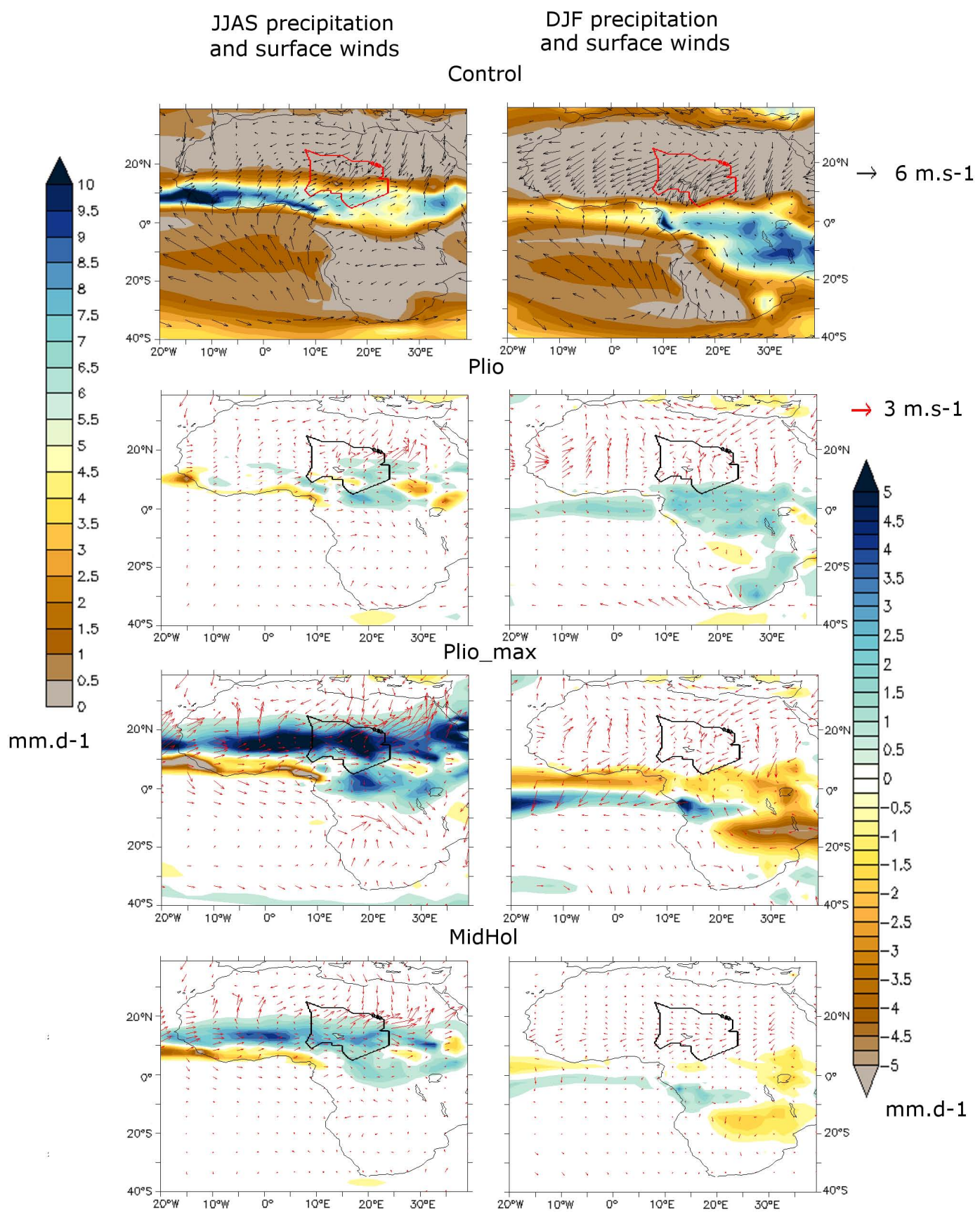

Fig. 5. Left: JJAS precipitation and mean low-level winds, anomalies to the control run. Right: the same for DJF.

shrubland up to $20^{\circ} \mathrm{N}$, which is comparable to the MidHol simulated vegetation (Fig. 9e and f). Plio_max displays a drastic reduction of the Sahara to the benefit of xerophytic shrubland, which reaches from $23^{\circ} \mathrm{N}$ on the western coast to $27^{\circ} \mathrm{N}$ on the eastern coast of Africa. Tropical woodland also covers an important area of central to eastern Africa between 11 and $17^{\circ} \mathrm{N}$. An $\sim 1^{\circ}$ northward shift of tropical savanna and a small patch of tropical deciduous forest/woodland appear at the east of MLC in the Plio_lake simulation (Fig. 9b). For Plio_max simulations, a narrow band of tropical wood- land can be seen at the southeast of MLC, and tropical xerophytic shrubland becomes temperate in the northwest of the Chad Basin. In this configuration, small changes outside of the Chad Basin are visible and consist of an expansion of temperate sclerophyll woodland and temperate xerophytic shrubland at the expense of desert on the west Mediterranean coast, and a slight northern shift of the desert boundary to the northwest of the Chad Basin when MLC is present (Fig. 9d). For the mid-Holocene simulation at $6 \mathrm{kyr}$ (Fig. 9e and f), with or without MLC, the simulated climate is not humid enough 
Precipitation and winds difference induced by the MLC in JJAS

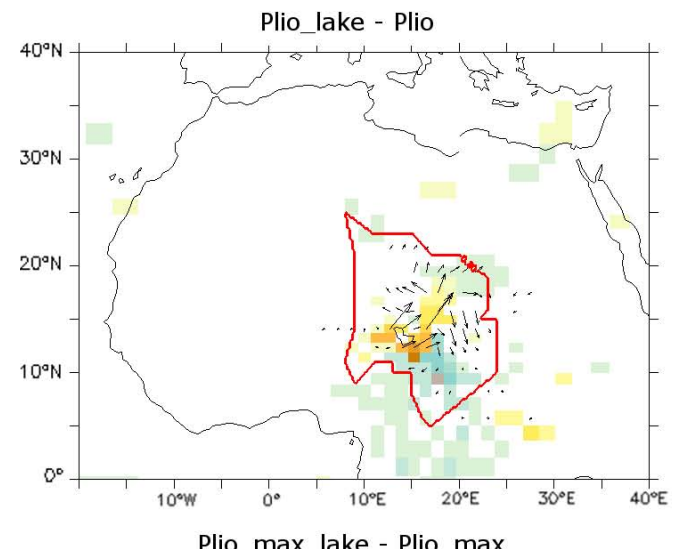

$\rightarrow 1 \mathrm{~m} \cdot \mathrm{s}-1$
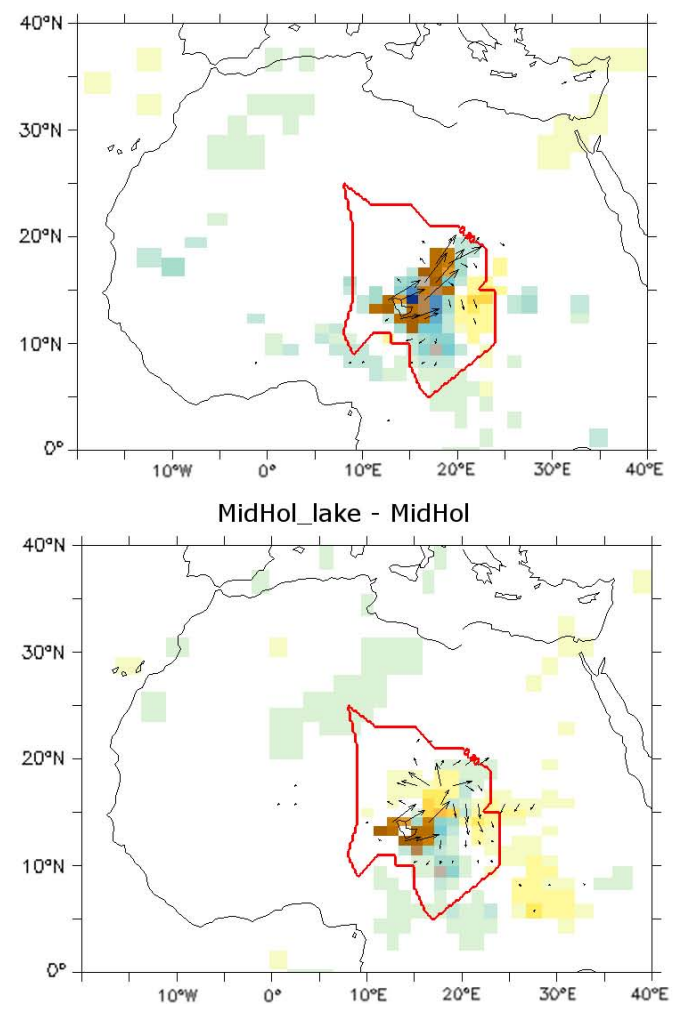

Fig. 6. JJAS precipitation and $10 \mathrm{~m}$ winds difference between "lake" experiments and standard experiment for each climatic configuration. Difference is significant at $95 \%$ in a Student's $t$ test.

to reproduce savanna biomes up to $20^{\circ} \mathrm{N}$, as suggested by vegetation reconstructions (Hoelzmann et al., 1998). This discrepancy is also seen in the MIROC model (e.g. Ohgaito et al., 2012). Changes induced by MLC consist in the appearance of tropical woodland in the southwest of MLC (Fig. 9f).
Surface temperature and slp difference induced by the MLC in JJAS
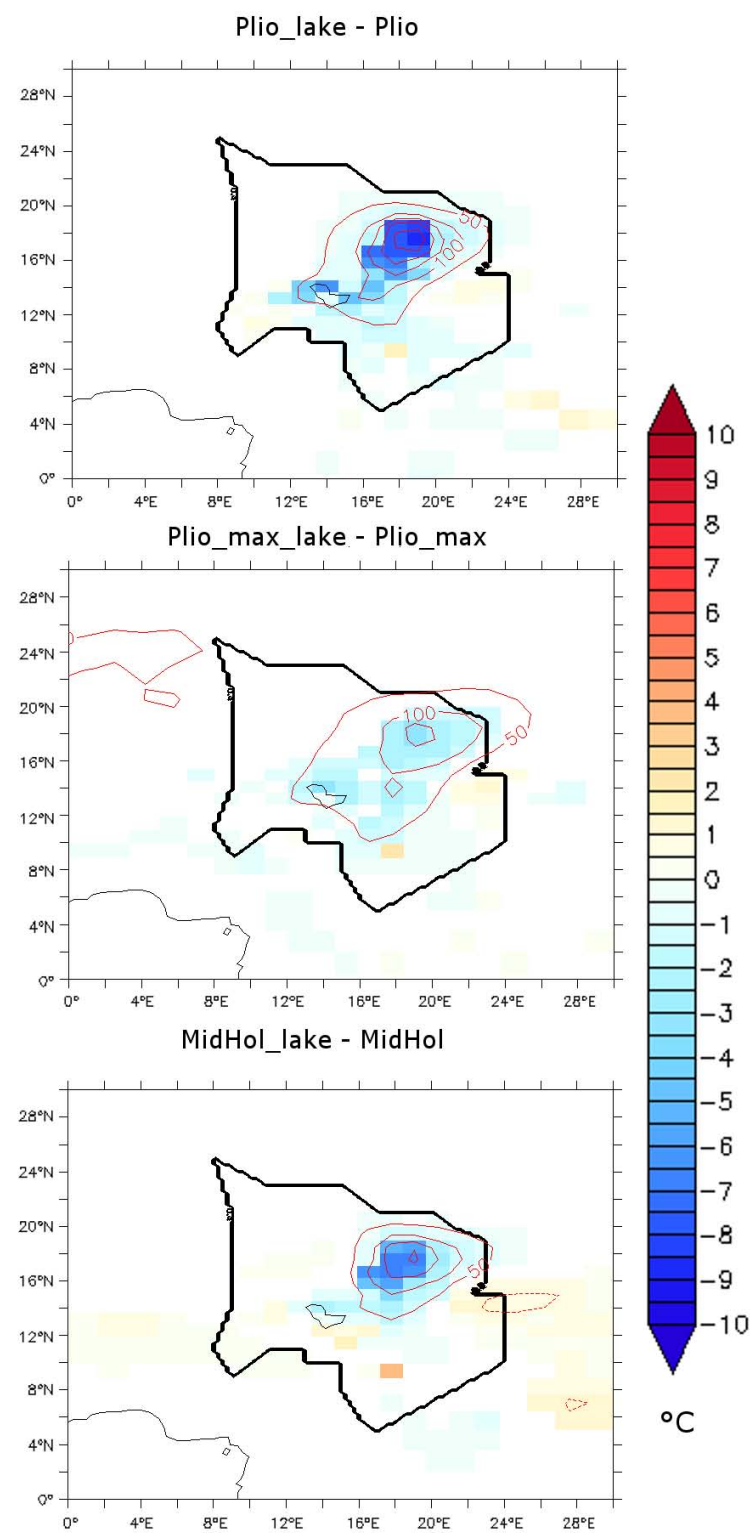

Fig. 7. JJAS surface temperature and sea level pressure (slp) difference between "lake" experiment and standard experiment for each climatic configuration. Temperature difference is significant at $95 \%$ in a Student's $t$ test. Sea level pressure difference is expressed in $\mathrm{Pa}$. Isolines every $50 \mathrm{~Pa}$.

\section{Discussion}

Morphosedimentary archives indicate an active Holocene hydrographic system flowing from the east (south Ennedi) associated with small-scale palaeodeltas which argue for riverine and lacustrine conditions (Ghienne et al., 2002; Schuster et al., 2005; Bouchette et al., 2010). For the Mio-Pliocene, fluvial deposits of the Koro-Toro, Kossom Bougoudi and 
Roughness length difference induced by the MLC

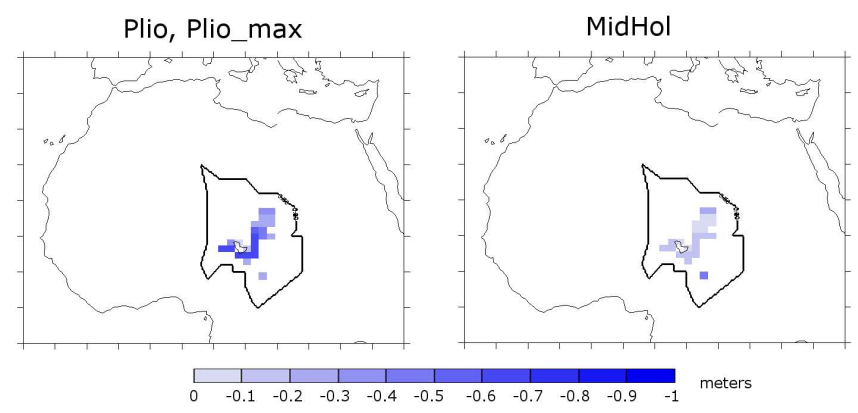

Fig. 8. Roughness length (m) difference between "lake" and standard experiments. The differences between mid-Holocene and Pliocene are due to different lake free vegetation distributions.

Kollé sites are attributed to ephemeral floods (Schuster, 2002). In a Pliocene context with present-day orbital parameters, the precipitation front reaches the Ennedi plateau, but total rainfall amount remains small $\left(250 \mathrm{~mm} \mathrm{yr}^{-1}\right)$. In Plio_max configurations, however, there is important precipitation over the Ennedi $\left(600 \mathrm{~mm} \mathrm{yr}^{-1}\right)$, even though MLC has a negative impact over precipitation in this area. The presence of MLC, which increases precipitation in the valley down the Ennedi (Fig. 6b), could have increased the outflow of these potential palaeorivers near their outlet into the lake. For the mid-Holocene, mean precipitation over the Ennedi is small (less than $200 \mathrm{~mm} \mathrm{yr}^{-1}$ ). In any configuration, precipitation over the Ennedi is restricted to summer months. Simulations also show that during the Pliocene and mid-Holocene, wind regime throughout the year is comparable to today, only with increased monsoon winds in summer. MLC amplifies this effect because of its flat surface, helping southwesterly winds to reach the northern shore of MLC. Similarly in winter, the Harmattan is increased over the lake surface.

The results presented above, showing a weak impact of surface conditions on North African climate, are in agreement with several studies (Coe and Bonan, 1997; Broström et al., 1998; Sepulchre et al., 2009). However, a recent study by Krinner et al. (2012, hereafter K12) described important regional-scale feedbacks of lakes and wetlands on the North African climate during the mid-Holocene, particularly by increasing precipitation and reducing droughts over a large part of North Africa. The K12 study uses the LMDZ4 model coupled to the land surface model ORCHIDEE with Hoelzmann et al. (1998) water surface conditions, which include MLC and some wetlands. The K12 study also has a different boundary layer parameterization compared to our study, which leads to better reproduction of observed precipitation in the Sahel region for the control run (see Krinner et al., 2012, Fig. 1). Tests carried out with our configuration but with the Hoelzmann et al. (1998) water surface conditions lead to inhibition of deep convection over MLC and wetlands, and weak redistribution of precipitation with no sig- nificant increase over the latitudinal average, suggesting the surface boundary condition is not the driver of the differences between the two studies. Although other relatively minor differences exist in the setup of K12 compared to this study, it seems the key factor triggering the higher sensitivity of the model to the presence of surface water in K12 study is the different boundary layer parameterization, which leads to more convection. The remote effect of surface waters in North Africa might thus be underestimated in state-of-theart climate models which have good skill on the global scale but which are not tuned to properly represent a given region. In our simulations, the megalake feedback is similar in the three climatic contexts; small biome changes outside the Chad Basin are only noticeable in the Plio_max configuration. This suggests a wider impact of MLC in a more humid background climate, the threshold to trigger a remote impact of MLC being harder to attain in our simulations than in K12 because of a standard parameterization of the boundary layer. Nevertheless, a robust feature is the reduction of deep convection because of colder surface, and redistribution of moisture in the north and east via increased surface winds and anticyclonic circulation. These mechanisms probably take place whenever a megalake is present in a warm climate. Remote impact of MLC alone or with extended wetland area is mostly not simulated in these studies, but the response of climate to this forcing is dependent on boundary layer parameterization, and may also be dependent on convection parameterization (Chikira et al., 2006).

Regarding biome distribution during the Pliocene, tropical savanna is present on the eastern shore of the lake, even in the Plio_lake configuration, i.e. with present-day orbital configuration, which is close to a glacial one in terms of precession angle, providing a habitable area for hominids during periods of relative droughts during the Pliocene. However, the presence of tropical savanna in this area is neither induced nor significantly favoured by MLC, and the presence of tropical savanna and more humid biomes in this area seems governed by global climate changes. Moreover, the extent of the Sahara seems to greatly vary throughout the Pliocene, depending on precession. With present-day orbital parameters, its southern limit is around $20^{\circ} \mathrm{N}$, whereas in the Plio_max configuration, it shifts up to $5^{\circ}$ northward, with tropical woodland reaching $18^{\circ} \mathrm{N}$.

\section{Conclusions}

The presence of a MLC during humid periods of the Cenozoic and Quaternary clearly impacts local precipitation and wind patterns. The most important feature is the suppression of deep convection above the surface of the lake. In summer, monsoon winds are increased over the lake surface, carrying humidity to the northeast. Over MLC, atmospheric pressure is slightly higher, a fact which also impacts wind circulation and explains the precipitation increase in the southeast 

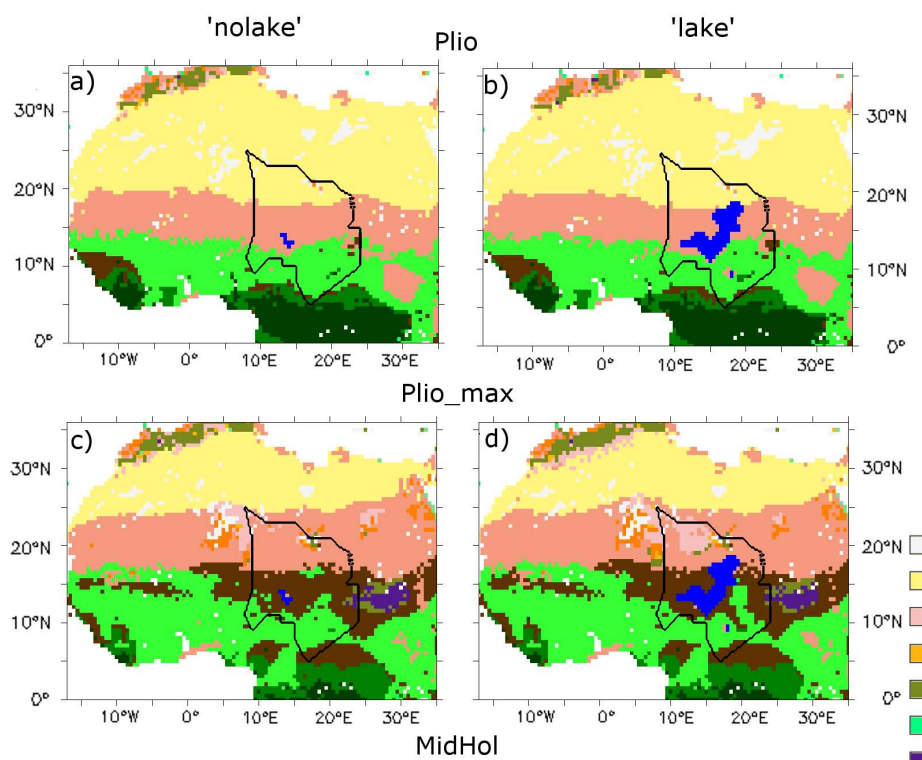

$$
\begin{aligned}
& 30^{\circ} \mathrm{N} \\
& 20^{\circ} \mathrm{N} \square \text { barren (soil) } \\
& \square \text { desert } \\
& 10^{\circ} \mathrm{N} \square \text { temperate xerophytic shrubland } \\
& \square \text { temperate grassland } \\
& 0^{\circ} \text { temperate sclerophyll woodland } \\
& \square \text { temperate conifer forest } \\
& \text { warm-temperate mixed forest }
\end{aligned}
$$
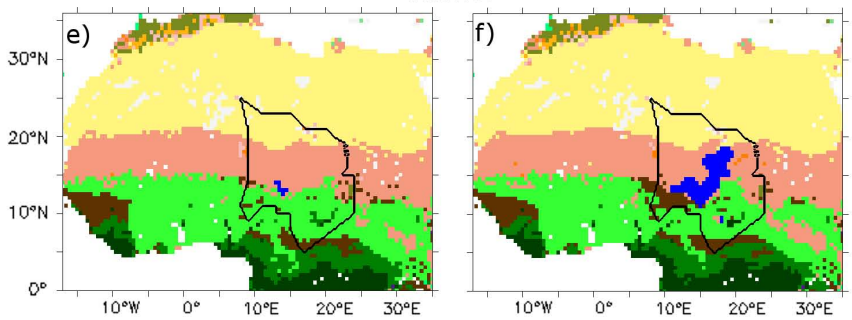

Fig. 9. Left: biome distribution for standard experiments. Right: the same for "lake" experiments.

of MLC. During the dry season, the presence of MLC does not generate precipitation over the basin. These results are a common feature of all the simulations. Impact away from the Chad Basin is weak, variable and dependent on boundary layer parameterization. We conclude that while MLC should be taken into account for its influence on climate in the Chad Basin, its influence alone outside the basin is still to be determined, and could be dependent on the background climate. In our study, the presence of MLC does not enhance a northward migration of the monsoon, in agreement with Broström et al. (1998). Regarding vegetation distribution, the presence of MLC has little effect on biomes, although humid biomes are simulated in the Chad Basin in all simulations, providing a sustainable environment for hominid populations, even if restricted to the southern part of the basin in the Plio simulation. The fact that environment was favourable for hominids during the late Pliocene but that MLC was not a major contribution to these conditions reinforces the hypothesis that climate change is the driver for these conditions, rather than surface hydrology changes. Other megalakes in present-day dry climates are documented for the Quaternary, such as megalakes Frome and Eyre in Australia (e.g. Alley 1998; Cohen et al., 2011), megalake Makgadikgadi in the Kalahari (Burrough et al., 2009) and Darfur megalake in Sudan (Gonheim and El-Baz, 2007), highlighting the im- portance of studying the impact of such water surfaces on the relatively arid present-day climates of these areas, which can be affected by the northward or southward migration of the monsoon.

Acknowledgements. CC would like to thank Yann Meurdesoif for providing a parallelized version of the model, Pascale Braconnot and Masa Kageyama for providing mid-Holocene SSTs and for fruitful discussions, and Guillaume Leduc for discussion on mid-Holocene data. We thank the reviewers Dan Hill and Aidan Farrow, who provided useful comments. This work was performed using HPC resources from GENCI - [CCRT/TGCC/CINES/IDRIS] (Grant 2012-GEN2212).

Edited by: C. Brierley

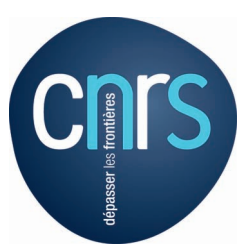

The publication of this article is financed by CNRS-INSU. 


\section{References}

Adler, R. F., Huffman, G. J., Chang, A., Ferraro, R., Xie, P., Janowiak, J., Rudolf, B., Schneider, U., Curtis, S., Bolvin, D., Gruber, A., Susskind, J., Arkin, P., and Nelkin; E.: The version 2 Global Precipitation Climatology Project (GPCP) monthly precipitation analysis (1979-present), J. Hydrometeorol., 4, 11471167, 2003.

Alley, N. F.: Cainozoic stratigraphy, palaeoenvironments and geological evolution of the Lake Eyre Basin, Palaeogeogr. Palaeocl., 144, 239-263, 1998.

Bouchette, F., Schuster, M., Ghienne, J.-F., Denamiel, C., Roquin, C., Moussa A., Marsaleix, P., and Duringer, P.: Hydrodynamics in Holocene lake Mega-Chad, Quaternary Res., 73, 226236, 2010.

Braconnot, P., Otto-Bliesner, B., Harrison, S., Joussaume, S., Peterchmitt, J.-Y., Abe-Ouchi, A., Crucifix, M., Driesschaert, E., Fichefet, Th., Hewitt, C. D., Kageyama, M., Kitoh, A., Laîné, A., Loutre, M.-F., Marti, O., Merkel, U., Ramstein, G., Valdes, P., Weber, S. L., Yu, Y., and Zhao, Y.: Results of PMIP2 coupled simulations of the Mid-Holocene and Last Glacial Maximum Part 1: experiments and large-scale features, Clim. Past, 3, 261277, doi:10.5194/cp-3-261-2007, 2007.

Broström, A., Coe, M., Harrison, S. P., Gallimore, R., Kutzbach, J. E., Foley, J., Prentice, I. C., and Behling, P.: Land surface feedbacks and palaeomonsoons in northern Africa, Geophys. Res. Lett., 25, 3615-3618, 1998.

Brunet, M., Beauvilain, A., Coppens, Y., Heintz, E., Moutaye, A. H. E., and Pilbeam, D.: The first australopithecine $2500 \mathrm{~km}$ west of the Rift Valley (Chad), Nature, 378, 273-275, 1995.

Brunet, M., Beauvilain, A., Geraads, D., Guy, F., Kasser, M., Mackaye, H. T., MacLatchy, L. M., Mouchelin, G., Sudre, J., and Vignaud, P.: Chad: a new Pliocene Hominids site, C. R. Acad. Sci. Paris, 324, 341-345, 1997.

Brunet, M., Guy, F., Pilbeam, D., Mackaye, H. T., Likius, A., Ahounta, D., Beauvilain, A., Blondel, C., Bocherens, H,. Boisserie, J. R., de Bonis, L., Coppens, Y., Dejax, J., Denys, C., Duringer, P., Eisenmann, V., Fanone, G., Fronty, P., Geraads, D., Lehmann, T., Lihoreau, F., Louchart, A., Mahamat, A., Merceron, G., Mouchelin, G., Otero, O., Campomanes, P., Ponce de Leon, M., Rage, J. C., Sapanet, M., Schuster, M., Sudre, J., Tassy, P., Valentin, X., Vignaud, P., Viriot, L., Zazzo, A., and Zollikofer, C.: A new hominid from the Upper Miocene of Chad, Central Africa, Nature, 418, 145-151, 2002.

Burrough, S. L., Thomas, D. S. G., and Singarayer, J. S.: Late quaternary hydrological dynamics in the Middle Kalahari: forcing and feedbacks, Earth Sci. Rev., 96, 313-326, 2009.

Chikira, M., Abe-Ouchi, A., and Sumi, A.: General circulation model study on the green Sahara during the mid-Holocene: an impact of convection originating above boundary layer, J. Geophys. Res., 111, D21103, doi:10.1029/2005JD006398, 2006.

Coe, M. T.: Modeling terrestrial hydrological systems at the continental scale: testing the accuracy of an atmospheric GCM, J. Climate, 13, 686-704, 2000.

Coe, M. T. and Bonan, G. B.: Feedbacks between climate and surface water in northern Africa during the middle Holocene, J. Geophys. Res., 102, 11087-11101, doi:10.1029/97JD00343, 1997.
Cohen, T. J., Nanson, G. C., Jansen, J. D., Jones, B. G., Jacobs, Z., Treble, P., Price, D. M., May, J.-H., Smith, A. M., Ayliffe, L. K., and Hellstrom, J. C.: Continental aridification and the vanishing of Australia's megalakes, Geology, 39, 167-170, doi:10.1130/G31518.1, 2011.

Contoux, C., Ramstein, G., and Jost, A.: Modelling the midPliocene Warm Period climate with the IPSL coupled model and its atmospheric component LMDZ5A, Geosci. Model Dev., 5, 903-917, doi:10.5194/gmd-5-903-2012, 2012.

Davis, B. A. S. and Brewer, S.: Orbital forcing and role of the latitudinal insolation/temperature gradient, Clim. Dynam., 32, 143165, doi:10.1007/s00382-008-0480-9, 2009.

deMenocal, P. B.: Plio-Pleistocene African climate, Science, 270, 53-59, 1995.

deMenocal, P. B.: African climate change and faunal evolution during the Pliocene-Pleistocene, Earth Planet. Sc. Lett., 220, 3-24, 2004.

Dolan, A. M., Haywood, A. M., Hill, D. J., Dowsett, H. J., Hunter, S. J., Lunt, D. J., and Pickering, S.: Sensitivity of Pliocene ice sheets to orbital forcing, Palaeogeogr. Palaeocl., 309, 98-110, 2011.

Dowsett, H. J., Robinson, M. M., Stoll, D. K., and Foley, K. M.: Mid-Piacenzian mean annual sea surface temperature analysis for data-model comparisons, Stratigraphy, 7, 189-198, 2010.

Dowsett, H. J., Foley, K. M., Stoll, D. K., Bentsen, M., OttoBliesner, B. L., Bragg, F. J., Chan, W.-L., Chandler, M. A. Contoux, C., Dolan, A., Haywood, A., Jonas, J. A., Jost, A., Kamae, Y., Lohmann, G., Lunt, D. J., Nisancioglu, K. H., Abe-Ouchi, A., Ramstein, G., Riesselman, C. R., Robinson, M. M., Rosenbloom, N. A., Salzmann, U., Sohl, L., Stepanek, C., Strother, S. S., Ueda, H., Ying, Q. and Zhang, Z.: Sea surface temperature of the mid-Piacenzian ocean: a data-model comparison. Nature Scientific Reports, 3, 2013, doi:10.1038/srep02013, 2013.

Drake, N. and Bristow, C.: Shorelines in the Sahara: geomorphological evidence for an enhanced Monsoon from palaeolake Megachad, Holocene, 16, 901-911, 2006.

Edwards, M.: Global Gridded Elevation and Bathymetry, in: Global Ecosystems Database, Version 1.0 (on CD-ROM), Documentation Manual, Disc-A: National Geophysical Data Center, Key to Geophysical Records Documentation No. 26 (Incorporated in: Global Change Database, Volume 1), edited by: Kineman, J. J. and Ohrenschall, M. A., Boulder, CO, National Oceanic and Atmospheric Administration, A14-1-A14-4, 1992

Ghienne, J. F., Schuster, M., Bernard, A., Duringer, P., and Brunet, M.: The Holocene giant lake revealed by digital elevation models, Quaternary Int., 87, 81-85, 2002.

Ghoneim, E. and El-Baz, F.: DEM optical radar data integration for palaeohydrological mapping in the northern Darfur Sudan: implication for groundwater exploration, Int. J. Remote Sens., 28, 5001-5018, 2007.

Griffin, D. L.: The late Neogene Sahabi rivers of the Sahara and their climatic and environmental implications for the Chad Basin, J. Geol. Soc. Lond., 163, 905-921, 2006.

Grove, A. T. and Pullan, R. A.: Some aspects of the Pleistocene palaeogeography of the Chad Basin, in: African Ecology and $\mathrm{Hu}-$ man Evolution, edited by: Howell, F. C. and Bourlière, F., Aldine Publishing Company, Chicago, 230-245, 1963. 
Hargreaves, J. C., Annan, J. D., Ohgaito, R., Paul, A., and AbeOuchi, A.: Skill and reliability of climate model ensembles at the Last Glacial Maximum and mid-Holocene, Clim. Past, 9, 811823, doi:10.5194/cp-9-811-2013, 2013.

Harrison, S. P. and Prentice, C. I.: Climate and $\mathrm{CO}_{2}$ controls on global vegetation distribution at the last glacial maximum: analysis based on palaeovegetation data, biome modelling and palaeoclimate simulations, Global Change Biol., 9, 983-1004, doi:10.1046/j.1365-2486.2003.00640.x, 2003.

Haxeltine, A. and Prentice, I.: BIOME3: an equilibrium terrestrial biosphere model based on ecophysiological constraints, resource availability, and competition among plant functional types, Global Biogeochem. Cy., 10, 693-709, 1996.

Haywood, A. M., Chandler, M. A., Valdes, P. J., and Salzmann, U.: Comparison of mid-Pliocene climate predictions produced by the HadAM3 and GCMAM3 general circulation models, Global Planet. Change, 66, 208-224, 2009.

Haywood, A. M., Dowsett, H. J., Otto-Bliesner, B., Chandler, M. A., Dolan, A. M., Hill, D. J., Lunt, D. J., Robinson, M. M., Rosenbloom, N., Salzmann, U., and Sohl, L. E.: Pliocene Model Intercomparison Project (PlioMIP): experimental design and boundary conditions (Experiment 1), Geosci. Model Dev., 3, 227-242, doi:10.5194/gmd-3-227-2010, 2010.

Haywood, A. M., Dowsett, H. J., Robinson, M. M., Stoll, D. K., Dolan, A. M., Lunt, D. J., Otto-Bliesner, B., and Chandler, M. A.: Pliocene Model Intercomparison Project (PlioMIP): experimental design and boundary conditions (Experiment 2), Geosci. Model Dev., 4, 571-577, doi:10.5194/gmd-4-571-2011, 2011.

Haywood, A. M., Hill, D. J., Dolan, A. M., Otto-Bliesner, B. L., Bragg, F., Chan, W.-L., Chandler, M. A., Contoux, C., Dowsett, H. J., Jost, A., Kamae, Y., Lohmann, G., Lunt, D. J., Abe-Ouchi, A., Pickering, S. J., Ramstein, G., Rosenbloom, N. A., Salzmann, U., Sohl, L., Stepanek, C., Ueda, H., Yan, Q., and Zhang, Z.: Large-scale features of Pliocene climate: results from the Pliocene Model Intercomparison Project, Clim. Past, 9, 191-209, doi:10.5194/cp-9-191-2013, 2013.

Hill, D. J.: Modelling Earth's Cryosphere during Pliocene Warm Peak, Ph. D. thesis, University of Bristol, UK, 368 pp., 2009.

Hill, D. J., Haywood, A. M., Hindmarsh, R. C. A., and Valdes, P. J.: Characterising ice sheets during the mid-Pliocene: evidence from data and models, in: Deep Time Perspectives on Climate Change: Marrying the Signal from Computer Models and Biological Proxies, edited by: Williams, M., Haywood, A. M., Gregory, F. J., and Schmidt, D. H., Micropalaeontol. Soc., Spec. Pub. Geol. Soc., London, 517-538, 2007.

Hoelzmann, P., Jolly, D., Harrison, S. P., Laarif, F., Bonnefille, R., and Pachur, H.-J.: Mid-Holocene land-surface conditions in northern Africa and the Arabian peninsula: a data set for the analysis of biogeophysical feedbacks in the climate system, Global Biogeochem. Cy., 12, 35-51, doi:10.1029/97GB02733, 1998.

Hourdin, F., Musat, I., Bony, S., Braconnot, P., Codron, F., Dufresne, J.-F., Fairhead, L., Filiberti, M.-A., Friedlingstein, P., Grandpeix, J.-Y., Levan, P., Li, Z.-X., and Lott, F.: The LMDZ4 general circulation model: climate performance and sensitivity to parametrized physics with emphasis on tropical convection, Clim. Dynam., 27, 787-813, 2006.

Huffman, G. J., Adler, R. F., Bolvin, D. T., and Gu, G.: Improving the global precipitation record: GPCP version 2.1, Geophys. Res. Lett., 36, L17808, doi:10.1029/2009GL040000, 2009.
Kageyama M., Braconnot, P., Bopp, L., Caubel, A., Foujols, M.A., Guilyardi, E., Khodri, M., Lloyd, J., Lombard, F., Mariotti, V., Marti, O., Roy, T., and Woillez, M.-N.: Mid-Holocene and Last Glacial Maximum climate simulations with the IPSL model, Part 1: comparing IPSL CM5A to IPSL CM4, Clim. Dynam., 40, 2447-2468, doi:10.1007/s00382-012-1488-8, 2013.

Kamae, Y. and Ueda, H.: Mid-Pliocene global climate simulation with MRI-CGCM2.3: set-up and initial results of PlioMIP Experiments 1 and 2, Geosci. Model Dev., 5, 793-808, doi:10.5194/gmd-5-793-2012, 2012.

Kaplan, J. O., Bigelow, N. H., Prentice, I. C., Harrison, S. P., Bartlein, P. J., Christensen, T. R., Cramer, W., Matveyeva, N. V., McGuire, A. D., Murray, D. F., Razzhivin, V. Y., Smith, B., Walker, D. A., Anderson, P. M., Andreev, A. A., Brubaker, L. B., Edwards, M. E., and Lozhkin, A. V.: Climate change and Arctic ecosystems: 2. modeling, paleodata-model comparisons, and future projections, J. Geophys. Res., 108, 8171, doi:10.1029/2002JD002559, 2003.

Krinner, G.: Impact of lakes and wetlands on boreal climate, J. Geophys. Res., 108, 4520, doi:10.1029/2002JD002597, 2003.

Krinner, G., Lézine, A.-M., Braconnot, P., Sepulchre, P., Ramstein, G., Grenier, C., and Gouttevin, I.: A reassessment of lake and wetland feedbacks on the North African Holocene climate, Geophys. Res. Lett., 39, L07701, doi:10.1029/2012GL050992, 2012.

Kusnir, I. and Moutaye, H. A. : Ressources minérales du Tchad: une revue, J. Afr. Earth Sci., 24, 549-562, 1997.

Laskar, J., Robutel, P., Joutel, F., Gastineau, M., Correia, A. C. M., and Levrard, B.: A long-term numerical solution for the insolation quantities of the Earth, Astron. Astrophys., 428, 261-285, 2004.

Lauwaet, D., Van Lipzig, N. P. M., Van Weverberg, K., De Ridder, K., and Goyens, C.: The precipitation response to the desiccation of Lake Chad, Q. J. Roy. Meteorol. Soc., 138, 707-719, doi:10.1002/qj.942, 2012.

Lebatard, A. E., Bourlès, D., Arnold, M., Duringer, Ph., Moussa, A., Jolivet, M., Braucher, R., Deschamps, P., Schuster, M., Roquin, C., Carcaillet, J., Lihoreau, F., Likius, A., Mackaye, H. T., Vignaud, P., and Brunet, M.: Application of the authigenic ${ }^{10} \mathrm{Be} /{ }^{9} \mathrm{Be}$ dating method to continental sediments: reconstruction of the Mio-Pleistocene sedimentary sequence in the early hominid fossiliferous areas of the northern Chad Basin, Earth Planet. Sc. Lett., 297, 57-70, 2010.

Leblanc, M., Favreau, G., Maley, J., Nazoumou, Y., Leduc, C., Stagnitti, F., van Oevelen, P. J., Delclaux, F., and Lemoalle, J.: Reconstruction of Megalake Chad using Shuttle Radar Topographic Mission data, Palaeogeogr. Palaeocl., 239, 16-27, doi:10.1016/j.palaeo.2006.01.003, 2006.

Leblanc M., Lemoalle, J., Bader, J.-C., Tweed, S., and Mofor, L.: Thermal remote sensing of water under flooded vegetation: new observations of inundation patterns for the "Small" Lake Chad, J. Hydrol., 404, 87-98, 2011.

Leduc G., Schneider, R., Kim, J.-H., and Lohmann., G.: Holocene and Eemian sea surface temperature trends as revealed by alkenone and $\mathrm{Mg} / \mathrm{Ca}$ paleothermometry, Quaternary Sci. Rev., 29, 989-1004, 2010.

Leemans, R. and Cramer, W.: The IIASA database for mean monthly values of temperature, precipitation and cloudiness of a global terrestrial grid, RR-91-18, International Institute for 
Applied Systems Analysis (IIASA), Laxenburg, Austria, 1991.

Maley, J.: Palaeoclimates of Central Sahara during the Early Holocene, Nature, 269, 573-577, 1977.

Marzin, C. and Braconnot, P.: Variations of Indian and African monsoons induced by insolation changes at 6 and $9.5 \mathrm{kyr} \mathrm{BP}$, Clim. Dynam., 33, 215-231, 2009.

Ohgaito, R., Sueyoshi, T., Abe-Ouchi, A., Hajima, T., Watanabe, S., Kim, H.-J., Yamamoto, A., and Kawamiya, M.: Climate and African precipitation changes in the mid-Holocene simulated using an Earth System Model MIROC-ESM, Clim. Past Discuss., 8, 3277-3343, doi:10.5194/cpd-8-3277-2012, 2012.

Olivry, J. C., Chouret, A., Vuillaume, G., Lemoalle, J., and Bricquet, J. P.: Hydrologie du Lac Tchad, ORSTOM, Paris, 259 pp., 1996.

Pias, J. and Guichard, E.: Origine et conséquences de l'existence d'un cordon sableux dans la partie sud-ouest de la cuvette tchadienne, C. R. Acad. Sci. Paris, 244, 791-793, 1957.

Pound, M. J., Haywood, A. M., Salzmann, U., Riding, J. B., Lunt, D. J., and Hunter, S. J.: A Tortonian (Late Miocene 11.61-7.25 Ma) global vegetation reconstruction, Palaeogeogr. Palaeocl., 300, 29-45, 2011.

Prahl, F. G., Rontani, J.-F., Zabeti, N., Walinsky, S. E., and Sparrow, M. A.: Summer-biased sea-surface temperature record for alkenones in SE Alaskan surface sediments, Geochim. Cosmochim. Acta, 74, 131-143, 2010.

Ritz, C., Rommelaere, V., and Dumas, C.: Modeling the evolution of Antarctic ice sheet over the last 420,000 years: Implications for altitude changes in the Vostok region, J. Geophys. Res., 106, 31943-31964, 2001.

Salzmann, U., Haywood, A. M., Lunt, D. J., Valdes, P. J., and Hill, D. J.: A new global biome reconstruction and data-model comparison for the Middle Pliocene, Global Ecol. Biogeogr., 17, 432-447, 2008.
Schuster, M.: Sédimentologie et paléoécologie des séries à vertébrés du paléolac Tchad depuis le Miocène supérieur, Université Louis Pasteur Strasbourg I, Strasbourg, 152 pp., 2002.

Schuster, M., Duringer, P., Ghienne, J.-F., Bernard, A., Brunet, M., Vignaud, P., and Mackaye, H. T.: The Holocene Lake MegaChad: extension, dynamic and palaeoenvironmental implications since upper Miocene, 11th European Union of Geoscience Meeting, Strasbourg, 2001.

Schuster, M., Duringer, P., Ghienne, J. F., Brunet, M., and Vignaud, P.: Coastal conglomerates around the Hadjer el Khamis inselbergs (Chad): new evidence for Lake Mega-Chad high water level episodes, Earth Surf. Proc. Land., 28, 1059-1069, 2003.

Schuster, M., Roquin, C., Brunet, M., Caugy, M., Duringer, P., Fontugne, M., Mackaye, H. T., Vignaud, P., and Ghienne, J.-F.: Holocene Lake Mega-Chad palaeoshorelines from space, Quaternary Sci. Rev., 24, 1821-1827, 2005.

Schuster, M., Duringer, P., Ghienne, J.-F., Vignaud, P., Mackaye, H. T., Likius, A., and Brunet, M.: The age of the Sahara desert, Science, 311, 5762, doi:10.1126/science.1120161, 2006.

Schuster, M., Duringer, P., Ghienne, J.-F., Roquin, C., Sepulchre, P., Moussa, A., Lebatard, A.-E., Mackaye, H. T., Likius, A., Vignaud, P., and Brunet, M.: Chad Basin: paleoenvironments of the Sahara since the Late Miocene, C. R. Geosci., 341, 603-611, 2009.

Sepulchre, P., Ramstein, G., and Schuster, M.: Modelling the impact of tectonics, surface conditions and sea surface temperatures on Saharan and sub-Saharan climate evolution, C. R. Geosci., 341, 612-620, 2009.

Sohl, L. E., Chandler, M. A., Schmunk, R. B., Mankoff, K., Jonas, J. A., Foley, K. M., and Dowsett, H. J.: PRISM3/GISS topographic reconstruction: US Geol. Surv. Data Series, 419, 6 pp., 2009.

Tilho, J.: Sur l'aire probable d'extension maximale de la mer paléotchadienne, C. R. Acad. Sci. Paris, 181, 643-646, 1925. 